\title{
Glass Ceiling or Slippery Floors? Understanding Gender Differences in the Spanish Worker's Compensation System
}

\author{
ALFONSO MORAL DE BLAS \\ Departamento Fundamentos de Teoría Económica, UNIVERSIDAD DE VALLADOLID, \\ ESPAÑA.E-mail: amoral@eco.uva.es
}

HELENA CORRALES-HERRERO

Departamento Economía Aplicada, UNIVERSIDAD DE VALLADOLID, ESPAÑA. E-mail: helena@eaee.uva.es

\begin{abstract}
ANGEL MARTÍN-ROMÁN
Departamento Fundamentos de Teoría Económica, UNIVERSIDAD DE VALLADOLID, ESPAÑA. E-mail: angellm@eco.uva.es
\end{abstract}

\begin{abstract}
The main goal of this paper is to analyse gender differences in the Spanish workplace accident insurance or worker's compensation (WC) system. More specifically, we are interested in understanding the differences between female and male employees in the duration of the recovery spell after a workplace accident. This will provide us with a better comprehension of the distinct opportunistic behaviour carried by men and women causing absenteeism. Our results show that women who are occupied in low-responsibility jobs experience unjustified longer periods of recovery than men. But, as the occupational ladder is climbed this pattern tends to disappear and, what is more striking, on top of the ladder women are found to be more job-committed than men. Besides, business cycle seems to have a greater effect on women than men.
\end{abstract}

Keywords: Moral Hazard, Opportunistic Behaviour, Worker's Compensation, Glass Ceiling.

\section{¿Techo de cristal o suelo resbaladizo? Comprendiendo las diferencias de género en el sistema de indemnización por accidente}

\section{RESUMEN}

El objetivo principal de este trabajo es analizar las diferencias de género asociadas al seguro por accidente de trabajo o al sistema español de indemnización a los trabajadores. Más específicamente, estamos interesados en entender las diferencias en el tiempo de recuperación después de un accidente de trabajo entre hombres y mujeres. Con ello conseguimos un conocimiento mejor de la conducta oportunista que genera el absentismo laboral. Los resultados muestran que las mujeres que ocupan puestos de trabajo de menor responsabilidad experimentan periodos injustificados de recuperación más prolongados que los hombres. Pero, según ascendemos en la escala ocupacional este comportamiento tiende a desaparecer y, lo que es más significativo, en la parte superior de la escala ocupacional las mujeres se encuentran más comprometidas con el trabajo que los hombres. Además, el ciclo económico parece tener un mayor efecto sobre el tiempo de recuperación de las mujeres que de los hombres.

Palabras clave: Riesgo moral, comportamiento oportunista, sistema de indemnización y techo de cristal.

Clasificación JEL: J28, J16, D82

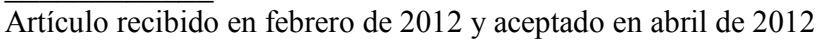

Artículo disponible en versión electrónica en la página www.revista-eea.net, ref. ə-30118 


\section{INTRODUCTION}

Nowadays there is an interesting debate on labour markets reforms. Commonly, political parties and unions argue about contracts, firing costs or collective bargaining. Nevertheless, employers' representatives are much more concerned with absenteeism. At the same time, the sustainability of the Welfare State as we know it is also under consideration due to the high costs that it entails. As an example of the relevance of the problem, a report carried out by Comisiones Obreras Union (CC.OO., 2004) has estimated that the economic cost of accidents at work in 2002 was 11,988 millions of Euros, what meant $1.72 \%$ of Gross Domestic Product ${ }^{1}$.

The main goal of this paper is to analyse gender differences in the Spanish workplace accident insurance or worker's compensation (WC) system. By doing this we achieve a twofold objective. On the one hand, we contribute to the literature on absenteeism from a different standpoint and with a dataset that, as far as we know, it has not been used for this purpose. On the other hand, we deepen into the question of moral hazard on worker's compensation, which may generate a very useful knowledge to design public policies to make the Welfare State more sustainable.

Data on labour accidents in Spain show that women absences are about three days higher than those of men. In other words, the average sick leave duration as a consequence of an accident at work is 16.8 days for male workers and 19.7 for female workers. That means a significant gender gap of $17.3 \%$, which is even more surprising since women tend to occupy less risky jobs than men. Nonetheless, before concluding anything it is necessary to identify which part of that gap is due to the different job and worker characteristics and which part may be attributable to a distinct behaviour. To give an answer to this question is the central aim of this paper.

The rest of the work is organised as follows. We present a brief discussion of the relevant theories that try to explain the difficulties found by women to promote in their job (when they are compared to men) in the second section. Section three reviews the academic literature related to this work. Section four describes the institutional settings affecting accidents at work. Section five explains the methodology. Section six presents the database used in the empirical analysis. Results are discussed in section seven. Finally, the concluding remarks and a summary are included in the last section.

\footnotetext{
${ }^{1}$ From another point of view (and for another country), it has been estimated that in a typical year in the United States, from one-half to one-third as many working days are lost due to workplace accidents than to unemployment and more than fifty times work days are lost as a result of injuries caused by accidents at work than as a result of labour strikes (Krueger, 1990).
} 


\section{GENDER DIFFERENCES IN THE LABOUR MARKET}

In order to contextualize this article in the broad academic literature on gender differences in the labour market and so as to better understand some results from the empirical part of this work, we devote this section to present a schematic view of some theories that have been proposed to explain why women usually find difficulties when they try to promote in their jobs.

To begin with, it is worth mentioning that gender differences in the labour market have attracted much attention among researchers for a long time. Traditionally, wage discrimination and occupational segregation have become two topics which have generated an important literature. More recently, it has been recognized that women are promoted less frequently than men to the upper levels of many professions (Blau and DeVaro 2007; Ransom and Oaxaca 2005). The reason behind these gender differences on top positions is not yet clear. Two main explanations have been suggested: the "glass ceiling" and the "sticky floor" hypotheses.

The "glass ceiling" hypothesis states that there is "(...) a transparent barrier that keeps women from rising above a certain level in corporations (...) It applies to women as a group who are kept from advancing higher because they are women" (Morrison et al. 1987). The seminal work by Lazear and Rosen (1990) can be considered as the formal view of the glass ceiling hypothesis. The basic idea behind this model is that women are promoted less frequently than men since the former abandon the labour market more often than the latter (because women have non-market opportunities at home). Due to this, employers require women a higher job performance for promotion in order to recover the investment in firm training ${ }^{2}$.

The "sticky floor" hypothesis may explain situations "where women are promoted as often as men, but receive lower gains consequent upon promotion. In firms with formal wage scales, women remain stuck to the lower wage point on the wage scale of their new, higher job grade" (Booth et al. 2003). These authors justify the lower promotion rate of women by turning to an explanation based on discrimination, both external (women have worse outside opportunities than men if they leave the firm) and internal (employers can respond differently to outside offer threats from women and men because of the discrimination).

These two approaches assume some kind of discrimination against women. In the end, the work by Lazear and Rosen (1990) turns to statistical discrimination in order to justify differences in promotion rates, while Booth et al. (2003) explicitly considers the discrimination-based explanation. In contrast with these

\footnotetext{
${ }^{2}$ Miller (2009) finds evidence of a glass ceiling effect at the extreme upper-end of the wage distribution in USA.
} 
hypotheses, there is the "dead-end" explanation for gender differences in promotion, which simply states that women are less often promoted than men to high-status jobs just because women tend to be employed in jobs that offer fewer opportunities for promotion, the so-called dead-end jobs (Groot and Van den Brink 1996). Insofar as women can choose freely their jobs, this would mean that, in some sense, women are determining their own future. The rationale underlying the question is that women are less committed to job and, at the same time, more committed to family than men $^{3}$. This implies that women tend to concentrate in occupations that require less effort ${ }^{4}$ but, simultaneously, lead them to fewer opportunities of promotion.

\section{PREVIOUS STUDIES}

The research developed in this paper is related to two strands of academic literature: studies on labour absenteeism and research on the incentives created by $\mathrm{WC}$ and the moral hazard problems associated with them. Before going into the enumeration of the more relevant research related to ours, let us delve into this question briefly.

The first thing that has to be taken into consideration is that if an individual extends his/her sick leave duration without physiological cause, this could be considered as an episode of absenteeism. The academic studies (from an economic standpoint) on absenteeism are already a vast literature. Without the aim of being exhaustive, it might be pointed out that the commonly accepted starting points are the works of Allen (1981a, 1981b) and that a seminal article which summarizes the early contributions is that of Brown and Sessions (1996) ${ }^{5}$. A recent example of this kind of bibliography referred to the Spanish case is Gamero-Burón (2010), where the author assesses the economic costs of workdays lost due to stress.

More importantly for our purposes, it is worth mentioning that the literature on labour absenteeism has frequently recognized that women tend to present higher levels of labour absenteeism than men. In this sense, there is a number of research works have performed ad hoc empirical exercises which have reached this result. Among them, we may quote Paringer (1983), Leigh (1983), Barmby et al. (1991), VandelHeuvel and Wooden (1995), Vistnes (1997), Bridges and Mumford (2001) and Ichino and Moretti (2009).

\footnotetext{
${ }^{3}$ Walker (2009) indicates that housework effort of self-employed women contributes to their lower earnings.

${ }^{4}$ This should be understood as less demanding jobs in a broad sense, but particularly less timedemanding jobs.

${ }^{5}$ Additional bibliography about the determinants of labour absenteeism can be found in the works of Johansson and Palme (1996), Barmby et al. (2002), and Henrekson and Persson (2004).
} 
Additionally, there is another group of studies which analyse the determinants of labour absenteeism from a more general standpoint (that is, not from a specific gender perspective). In these works it is quite usual to include a variable to capture gender in the econometric specification, and they also conclude that women are more prone to be absent than men. Some examples are Leigh (1984), Barmby and Treble (1991) and Ichino and Riphahn (2005). Finally, it is necessary to indicate that there are also some studies in which the comparison between both sexes shows less conclusive results, as for instance Kenyon and Dawkins (1989), Chaudhury and Ng (1992), Drago and Wooden (1992), Brown (1994), and Engellandt and Riphahn (2005). A recent work that enquires into the question of labour effort for the Spanish case is Rodríguez-Gutierrez and Canal-Domínguez (2012). Although, strictly speaking, it cannot be considered a paper on absenteeism, the authors find that women tend to put less effort at work than men, a result closely related with those above mentioned.

A second type of studies that are linked with our paper are those analysing moral hazard issues related to workplace accident insurance. We should not forget that WC protects the insured against income losses and, as a result, it may change worker's decisions concerning leisure time (understanding by leisure that time not devoted to work at the market). In other terms, there exists a moral hazard problem in the insurance for workplace accidents, as the economic bibliography has emphasized.

A good reference to deepen this subject is the book chapter by Fortin and Lanoie (2001). There, those authors identify up to four types of moral hazard related to the workplace accident insurance. The first type is called ex ante injury hazard. Workers have fewer incentives to take care of themselves when exists insurance that covers financial and medical costs of accidents, what implies a greater possibility of being injured. A second type of moral hazard is called ex ante causality hazard. This type occurs because it is sometimes hard to recognize which injuries are job-related. For this reason, employees might file claims for off-the-job accidents. A third type could be named ex post duration hazard, which causes an increase in the length of the recovery spell as a consequence of an opportunistic behaviour carried out by workers. A fourth form might be termed substitution hazard and it arises because the workplace accident insurance could be more generous than other types of insurance, as for example the unemployment benefits. So, when employees face a dismissal, they might take actions in order to obtain accident insurance payments instead of unemployment benefits, for instance by reporting false accidents or by increasing the duration of the recovery period. This paper focuses on the third type of moral hazard. In particular, gender differences on duration are addressed trying to find out if women behave more opportunistically than men and also if such behaviour is homogeneous regardless of the type of occupation. 
The amount of papers examining different aspects of labour safety and moral hazard is huge. The interested reader may consult the recent work by Pouliakas and Theodoropoulos (2010) for a detailed and state-of-the-art survey. As for the Spanish case, the literature analysing workplace accidents, from a general point of view, has been an increasing interesting topic in recent years. Although it is worth pointing out that the issue of differences between genders has hardly addressed.

Instead, authors have focused on the role of temporary contracts for explaining differences in frequency rates (Amuedo-Dorantes 2002; Guadalupe 2003; Hernanz and Toharia 2006). On the other hand, García-Serrano et al. (2010) analyse the effect of contracts signed via temporary work agencies on both the probability of suffering a serious/fatal accident and the number of working days lost after an accident has happened.

Apart from pure contractual issues, other kinds of aspects have taken into account. For example, Corrales et al. (2008) examine differences in the recovery period after an accident in the Spanish regions. García-Mainar and MontuengaGómez (2009) explore the determinant factors behind labour accidents at work both from a regional and an industry perspective. Finally, Moral de Blas et al. (2010) puts the focus on differences associated with the nationality of the workers.

Finally, and more closely related to this paper, Martin-Roman and Moral (2008) focuses on gender differences in the reporting of certain types of injuries (strains, sprains and low back lesions), the so-called hard-to-diagnose, softtissue or easy-to-conceal injuries. The reason for selecting those lesions is the belief that such injuries are more prone to be affected by opportunistic behaviour. The initial difference is 11 percentage points over a reporting rate $41 \%$ for male workers. These authors conclude that after controlling for a set of covariates there remains a significant gap ( 7 out of 11 percentage points might be considered as unjustified) which indicates that women incur more intensively than men in ex ante causality hazard. The current paper tries to complete the picture from the perspective of ex post duration hazard.

\section{INSTITUTIONAL SETTINGS}

Spanish salary workers participate in a collective public insurance integrated in the health system which covers both sicknesses and injuries (common or work-related). This section is devoted to explain some features of the Spanish workers' compensation system in relation to accidents at work.

According to article 115 of the Spanish General Law on Social Security (Ley General de la Seguridad Social) a workplace accident is defined as "any accident causing injury suffered by the employee in the course of his/her employment or in circumstances arising from employment." As a consequence of a 
work-related accident, workers may be unable to perform his/her work. The absence from work has social, labour and economic implications. The indemnity benefits seek to compensate partially the loss of productivity. The system also covers medical expenditures and other costs required for the recovery.

The most common type of indemnity is the one for temporary impairments (TI) (in opposition to permanent impairments). In this case, the worker is unable to work but he/she is expected to be fully recovered and to return to work. In case of work-related accidents, eligibility for the indemnity benefit do not require any minimum period of contribution and workers may receive the benefit ( $75 \%$ of earnings) for a maximum of 18 months. After this period, the worker must either return to work or to pass a medical examination to be considered as permanently disabled.

To manage properly resources allocated to this measure of social protection, it is vital an adequate medical prescription of TI and most specially, a precise determination of the duration of TI. With regard to duration, the decision on when the worker is totally recovered to perform his usual tasks in the workplace is essentially taken by a physician, and it should be strictly based on medical criteria. In this sense, since 1994 medical doctors from the Spanish National Institute of the Social Insurance (INSS) and doctors from the Mutual companies of Workplace Accidents and Occupational Diseases of the Social Security (MATEPSS) are responsible for assessing if the health status of injured worker is satisfactory enough to return to work. For this purpose, workers are forced to make regular visits (every seven days) to the doctor to confirm their disability for work.

Therefore, the duration of non-work spells in the Spanish workers' compensation system depends basically on factors related to the injury caused by the workplace accident and particularly, to the nature and severity of the impairment.

However, several studies (Johnson and Ondrich, 1990; Cheadle et al., 1994; Butler et al., 2001; Campolieti et al., 2008) have shown that return to work after a work-related injury is also determined by other factors like worker's characteristics. This occurs mostly in hard-to-diagnose injuries whose evaluation is affected by some degree of uncertainty and for which there is not an optimal treatment (Campolieti, 2001). In these cases, workers have some control to lengthen (or shorten) the recovery time and, in consequence, the benefit for TI can have a clear effect on labour activity (Neuhauser and Raphael, 2004).

\section{METHODOLOGY}

The main objective of this study is to identify unjustified gender differences in the injured worker's recovery period and how these differences vary with occupations. To reach this objective a two-step approach is carried out. First, 
duration models are used to identify the most relevant factors that determine the days of absence from work caused by a workplace accident. Second, a nonlinear decomposition is used to explain the gender differences in the duration of the recovery period.

Duration models are the most appropriate statistical methodology to study the occurrence and duration of an event. The core objective is to analyze a continuous non-negative variable, $T$, which informs about the time spent in a state, that is, the working days lost as a result of a work-related accident. Then, we define the hazard function, $h(t, X)$, which measures the instantaneous probability that an individual leaves the state at time $t$, conditional to not having left till the moment immediately before. In our case, it is the conditional probability that a worker returns to his/her job at time $t$,

$$
h(t ; X)=\lim _{\Delta t \rightarrow 0} \frac{p[t \leq T<t+\Delta t / T \geq t ; X]}{\Delta t} .
$$

A quantitative assessment of the effect of the explanatory variables $X$ requires the estimation of parametric or semi-parametric models. A model frequently used in economics is the semi-parametric Cox model (Cox, 1972). The fundamental assumption of this model is to separate the time effect from other factors, specifying the hazard function as $h(t ; X)=h_{0}(t) \cdot e^{x \beta}$, where $h_{0}(t)$ is an unknown baseline hazard function for a mean individual. Thus, the effect of any explanatory variable is to multiply the hazard by a factor which does not depend on $t$.

Nevertheless, some studies focus on duration dependence and use parametric models. Duration dependence will be positive (negative) if the conditional probability that a worker returns to work is greater (smaller) as he/she stays more time unable for work. The parametric estimation need to assume a statistical distribution for the hazard function (exponential, Weibull, log-logistic...) and the shape parameter determines the duration dependence.

The second part of our empirical analysis is devoted to study gender differences. One of the most interesting aspects in the comparison of groups is to find out if differences are justified by the differences in observed characteristics. Oaxaca (1973) and Blinder (1973) implemented a method for this type of analysis that has been widely applied to study wage discrimination. However, the Oaxaca-Blinder decomposition has two limitations. First, it may only be applied to linear models and second, there are identification problems in the detailed decomposition (Oaxaca and Ransom, 1999).

In the literature there are studies that already decompose non-linear models.For example, Even and Macpherson (1990), Nielsen (1998), Fairlie (1999), Fairlie (2005), Motellón and López-Bazo (2005), Yun (2005) and Hernanz and 
Toharia (2006) decompose probit or logit functions. However, Yun (2004) provides a generalization of Oaxaca-Blinder methodology for a non-linear model that solves the identification problem.

In accordance with Yun (2004), if $Y$ is a non-linear function $\varphi$ of a linear combination of explanatory variables, we can decompose the mean difference of $Y$ between groups 1 and 2, according to the following expression:

$$
\bar{Y}_{1}-\bar{Y}_{2}=\left[\overline{\varphi\left(X_{1} \beta_{1}\right)}-\overline{\varphi\left(X_{2} \beta_{1}\right)}\right]+\left[\overline{\varphi\left(X_{2} \beta_{1}\right)}-\overline{\varphi\left(X_{2} \beta_{2}\right)}\right],
$$

where $X$ is a row vector of independent variables and $B$ is a vector of coefficient estimates. The first term above reflects the portion of the differential attributed to differences in characteristics (characteristic effect), and the second term is the portion due to differences in returns to characteristics (coefficients effect).

From this aggregated decomposition, Yun finds the contribution of each variable to the total difference (detailed decomposition) and proposes the following equation:

$$
\bar{Y}_{1}-\bar{Y}_{2}=\sum_{i=1}^{T} W_{\Delta X}^{i}\left[\overline{\varphi\left(X_{1} \beta_{1}\right)}-\overline{\varphi\left(X_{2} \beta_{1}\right)}\right]+\sum_{i=1}^{T} W_{\Delta \beta}^{i}\left[\overline{\varphi\left(X_{2} \beta_{1}\right)}-\overline{\varphi\left(X_{2} \beta_{2}\right)}\right] \text {, }
$$

Where

$$
\begin{gathered}
W_{\Delta X}^{i}=\frac{\left(\bar{X}_{1}^{i}-\bar{X}_{2}^{i}\right) \beta_{1}^{i}}{\sum_{i=1}^{T}\left(\bar{X}_{1}^{i}-\bar{X}_{2}^{i}\right) \beta_{1}^{i}} ; W_{\Delta \beta}^{i}=\frac{\bar{X}_{2}^{i}\left(\beta_{1}^{i}-\beta_{2}^{i}\right)}{\sum_{i=1}^{T} \bar{X}_{2}^{i}\left(\beta_{1}^{i}-\beta_{2}^{i}\right)} \\
\sum_{i=1}^{T} W_{\Delta X}^{i}=\sum_{i=1}^{T} W_{\Delta \beta}^{i}=1,
\end{gathered}
$$

and $T$ is the number of variables.

In this case, if we use dummy variables, the coefficients effects attributed to individual variables are not invariant to the choice of the omitted group. To solve the identification problem in the detailed decomposition Yun devises an algorithm for obtaining the normalized regression. This normalization can be found in Yun (2005) and in the Appendix II.

Following Corrales et al. (2008) and Martín-Román and Moral (2008), the coefficients effect is interpreted as a relative measure of the moral hazard. In other words, similar characteristics that have different returns are interpreted as an indicator of an opportunistic behaviour.

\section{DATA}

Given that the paper studies the duration of TI as a result of a workplace accident, the data that provide more information in relation to this issue come from the Statistics on Accidents at Work (Estadistica de Accidentes de 
Trabajo). Data are compiled by the Spanish Ministry of Labour and Social Affairs on an annual basis from accidents registered by employers. Administrative records contain information on the injured worker's characteristics, on the type and severity of the injury and on the characteristics of the company in which the person was working at the moment of the accident, as well as some dates to calculate the duration of TI and the total compensation received by worker.

This data source includes the total accidents occurred in a year that resulted in at least a day out of work (starting the time of absence the day after the accident). This study only focuses on the duration of TI, leaving aside permanent impairments and fatalities. So, we have selected accidents occurred between 1997 to 2001 in which the worker recovers from his/her injuries, which represent about $70-80 \%$ of the total accidents with absence. This selection also removes some observations that do not include information about the time when the worker returns to work. ${ }^{6}$

Besides, keeping in mind the basis of return-to-work model, we restrict the sample to those accidents having produced an injury without a standard treatment, such as sprains, twists and lumbar pains (the so called hard-to-diagnose injuries), for which the recovery also depends on the patient's own sensations. The selection of this type of injury can be carried out using two variables (or a combination of them): the part of the body injured and the type of injury. In our case, it has been carried out from the description of the injury, restricting to "Twists, sprains or distensions" (code 32) and "Lumbar pain" (code 33). These lesions are quite frequent, representing more than $40 \%$ of total injuries in the occupational accidents. After checking for errors in data, the analysis was carried out with $1,385,301$ observations corresponding to workers suffering from a hard-to-diagnose injury due to a work-related accident and losing work days for this reason at some time between 1997 and 2001. The final sample includes $1,078,591$ men and 306,710 women.

In relation to our key variable, the duration of absence from work (measured in days), a previous descriptive analysis indicates that non-work spells are typically short, $94 \%$ of spells last less than two months, being the most common the ones that do not exceed one month (81\%). The maximum duration is 447 days, just below the legal limit for temporary disabilities (540 days).

Table A1 in Appendix I contains a summary of the variables used in the analysis. In particular, it includes the total number of accidents, the percentage of injured women and the number of days out of work separately by gender. It can be observed that female accidents suppose less than one quarter of total

\footnotetext{
${ }^{6}$ This period was chosen because from 2002 some changes in the statistics makes more difficult to select the hard-to-diagnose injuries.
} 
accidents and female duration is three days longer than that of men. The simple comparison in terms of duration is potentially misleading since there are gender differences that are not taken into account, such as the structure of the economic activity or the occupational composition for each group.

Nevertheless, relevant differences are found out in the percentage of women (as a proportion of injured workers), ranging from $57 \%$ for Clerical support workers to $2 \%$ for those who belong to the Special scheme of coal mining. More specifically, the percentage of women is higher if the injury is serious or it involves hospitalization, if it occurs making non-habitual tasks or takes place going out or returning to the workplace (in itinere). The percentage of women is also higher if the injured worker belongs to a large company, has a fix-term contract, contributes to the Special scheme for agricultural or is working during the weekend. Finally, a higher proportion of women can be observed if the injured worker is a young or is working in Financial or insurance activities.

The duration of the absence from work spells also presents some striking outcomes. It can be seen that duration is lower for low-skilled workers, an occupational group where the male proportion is greater and, at the same time, the gender gap in duration is higher than for other occupational groups. On the contrary, the gender gap is lower and even there is a reversal relation for managers. There seems that women change their behaviour once the glass ceiling is broken.

In general terms, there are longer durations in the case of serious injuries, in those accidents that occur during the journey to work and in those that happen when workers are carrying out non-habitual tasks. Besides it is true that the average duration is higher in the following cases: in very large companies, in those situations where workers have a permanent contract, if the accident occurs in jobs associated with the regimes of the sea and the coal, if the job is related to activities such as water or energy, or if the injured person belongs to certain activities related to the tertiary sector. Finally, it can be noted that longer durations are concentrated in older workers, in accidents at weekends, or when the workday exceeds six hours.

\section{RESULTS}

To detect those relevant factors that have an influence on the number of days that a worker is absent due to an accident at work, duration models are used. To explain gender differences and to confirm whether the gap gender also occurs in the case of those occupations requiring a high-level of qualification a non-linear decomposition is applied.

A first approach to analyze the duration of the absence from work is carried out through the estimation of the Kaplan-Meier survival functions for the different subgroups defined by each factor. To test if survival curves are equal a log- 
rank test has been used. In Table 1 appears the chi-squared statistic for the logrank test that allows us to confirm that differences in the survival curves are statistically significant.

Table 1

Log-Rank test of equal survival curves

\begin{tabular}{lcc}
\hline & Women & Men \\
\hline Age at the time of the accident & 6111.68 & 21620.76 \\
Occupation & 1102.51 & 4831.91 \\
Social Security Scheme & 194.33 & 1727.84 \\
Type of contract & 1934.57 & 7862.41 \\
Size of firm & 1377.70 & 3683.37 \\
Economic activity & 2842.62 & 4618.10 \\
Mode of injury & 6692.37 & 21292.73 \\
Level of severity & 372.90 & 1520.64 \\
Part of the body injured & 5456.19 & 29124.40 \\
Number of hours worked previous to accident & 104.26 & 402.42 \\
Shift work & 178.62 & 664.62 \\
Day of the week & 95.02 & 1514.24 \\
Place of the accident & 4554.29 & 6690.38 \\
Year of the accident & 38.02 & 525.35 \\
Hospitalization required & 1538.39 & 2657.87 \\
Habitual work & 1062.92 & 1638.92 \\
\hline
\end{tabular}

Source: Own elaboration.

As it has been justified, a model that tries to explain the duration of temporary impairments resulting from an accident at work must assume that the time a worker is absent from work is determined by many factors, apart from strict medical reasons. This occurs specially in those situations in which the diagnosis and the treatment of injuries are subject to a high degree of uncertainty (hard-to-diagnose injuries).

As we have explained previously, semi-parametric modelling (Cox model) supposes that the proportional hazards assumption is applied, but in our case it is not suitable for all variables. On the other hand, the parametric modelling involves admitting some distribution for the hazard function selected among some usual distributions (exponential, Weibull, lognormal, etc.). For choosing 
the distribution that best fits our hazard function, we take into account the habitual tests. ${ }^{7}$

Following this parametric approach, the log-logistic function has been chosen. Based on this distribution and taking into consideration the fact that the shape of the hazard function is not always identical for all individuals, a loglogistic model with an auxiliary parameter is estimated. ${ }^{8}$ The expression of the hazard function for the log-logistic distribution is

$$
h(t ; x)=\frac{\lambda \gamma t^{\gamma-1}}{1+\lambda t^{\gamma}},
$$

where $\gamma$ is the shape parameter and $\lambda$ is the scale parameter. The former determines the duration dependence and it is a function of some characteristics of the accident or the injured worker.

The results of the log-logistic model are presented in Table A2 of the Appendix I. The upper part of the table includes the effects of various factors that define the scale parameter. To interpret the results we have to take into account that the log-logistic model is an accelerated hazards model. Then, a positive sign in a coefficient implies that this factor is slowing the process or, in other words, it increases the time it will take the injured worker to recover (a longer duration).

As one would expect, factors related to the severity of the injury are those that involve greater durations. Specifically, the first assessment of the injury by the doctor who examines employee just after the accident is the variable that has a major effect on duration. For its part, being treated in a hospital is also a significant and determining factor on explaining duration. With regard to this result, it should be noted that the time employees are off work includes also the days of hospitalization because data do not contain information about time spend in hospital.

With respect to those variables relating to personal and employee characteristics (age, seniority, occupation, type of contract or Social security scheme), the overall conclusion is that they usually show the expected sign. More specifically, age complicates the healing by delaying the time at which the employee returns to his/her habitual tasks. Moreover, workers with more seniority, permanent contracts and leadership positions are the ones which have longer durations.

\footnotetext{
${ }^{7}$ Results are available from the authors upon request.

${ }^{8}$ In a similar way of Butler et al. (2001) that allow duration dependence effects to vary with worker characteristics.
} 
Another group of factors included in the model is directly related to the accident, as the day of the week, the number of hours worked when the accident occurred, the place of the accident, the mode of injury, and the geographical area of the workplace. We emphasize two outcomes related to the place of the accident and the region. First, injuries after an accident in which the worker was outside his/her workplace (either going to or coming from work -in itinere- or in the journey to work) entail a longer duration than the ones that do not involve displacement. One explanation for this finding may be that jobs that require travelling need that the worker is fully recovered to do his work without the risk of a relapse. Second, we also found significant differences between regions. In particular, in the northern regions (Asturias, Cantabria, Galicia and País Vasco) the duration is longer.

Other control variable is related to the economic cost of the absence from work, such as the benefit indemnity. In the Spanish system the amount of compensation is a constant proportion of total contribution. The estimation shows that the benefits seem to be only relevant for males and that the bigger the benefit, the longer the absence from work. Concerning to economic variables, the unemployment rate is one of the common factors that it is used to explain sick leaves. Literature usually documents a positive relation between the unemployment rate and the speed of the recovery for salary workers (Leigh, 1985; Johansson and Palme, 2005). Our data does not cover a complete business cycle, but the unemployment rate has suffered great variation, reaching its minimum value in the third quarter of $2001(10.3)$ and its maximum value at the beginning of 1997 (21.3). For this reason, we have included the unemployment rate associated to the last quarter of the sick leave as an explanatory variable in the model, differentiating between male and female. ${ }^{9}$ Results show that the unemployment rate has a significantly negative effect on the recovery rate both for men and women, what support previous empirical studies. In particular, a one unit increase in the unemployment rate, decreases the survival time by $13.8 \%\left(100 *\left(\mathrm{e}^{-0.184}-1\right)\right)$. For females, the effect of an increase in the unemployment rate is stronger as the decreasing factor is 0.84 . In other words, the duration of sick leave is 0.84 times as large as in the baseline scenario. Then, the overall results are mostly in line with theoretical considerations about incentives to work and moral hazard considerations.

In relation to the main factor in our analysis, occupation shows clear differences between men and women. For men, the coefficients for any type of occupation are always positive, which means that their duration is greater than those of workers with elementary occupations (the reference group). Moreover, it is noted that occupations that require more responsibility, show higher

\footnotetext{
${ }^{9}$ The authors would like to acknowledge to an anonymous referee for suggesting the inclusion of this variable.
} 
coefficients. The results are clearly different in the case of women, so that the duration is even lower for women occupying high-responsibility jobs. These results agree with previous descriptive analysis and may be interpreted in terms of the opportunity costs of being away from work. These differences justify the second part of our study in which we apply a nonlinear decomposition disaggregating the results by occupations.

The second part of Table A2 evaluates the duration dependence (shape parameter). First, it should be noted that the hypothesis that duration dependence is identical regardless of the accident characteristics is rejected. Variables such as the place of the accident, the severity of the injury or the hospitalization modify the shape of the hazard function, both for men and women. To interpret the parameters it is necessary to bear in mind that a positive sign in the estimated coefficient means positive duration dependence. In other words, a positive change in that factor increases the value of the shape parameter.

The non-linear decomposition allows us to add a different perspective to the above duration analysis. The aim of the aggregate decomposition is to separate out differences in the duration into differences due to distributional differences in the sample characteristics (the variables included in the model) and those due to differences in the coefficients. Obviously, differences occur because men and women are employed in different sectors, they do not have identical occupations or suffer different types of accidents. The differences that are not explained by differences in characteristics could be considered as not justified.

Table 2 shows the results of the aggregated decomposition. Only $39 \%$ of the difference is justified by different characteristics of the two groups of injured workers. That is, if women share the same characteristics than men, their absence from work would last about one day less. However, nearly $61 \%$ of the difference is explained by a different impact of the observed characteristics in each group. Therefore, this $61 \%$ means that a variable has a different effect on duration depending on whether the injured worker is a man or woman.

Table 2

Results from the aggregated decomposition of the estimated duration difference on the absence from work between men and women

\begin{tabular}{ccc}
\hline Difference & Justified & Unjustified \\
\hline 3.6 & $39 \%$ & $61 \%$ \\
\hline
\end{tabular}

Source: Own elaboration.

On the other hand, the descriptive analysis and the duration model showed a differential gender effect associated with the occupation that seems to suggest that women are less prone to have absence episodes in high skilled occupations. 
Due to this, the second part of the decomposition analysis is devoted to study the effect of occupation. As it was explained before, we can obtain the contribution of each variable to the total difference (the detailed decomposition) following the procedure proposed by Yun (2004).

Because the log-logistic duration models include scale and shape parameters, the method used by Yun (2004) and the proposed weights are not applicable to this case. Nevertheless, this decomposition can be used for simpler models such as log-linear regression. This method has been used previously in the literature for non-censored duration data (Campolieti and Hyatt, 2006). Here, we follow the same procedure.

Table 3

Contribution to the duration difference of occupational variables in detailed decomposition. Log-linear estimation

\begin{tabular}{|c|c|c|c|c|}
\hline & & & & \\
\hline & \multicolumn{2}{|c|}{ Justified } & \multicolumn{2}{|c|}{ Unjustified } \\
\hline Occupation & & $\%$ & & $\%$ \\
\hline Managers & -0.00001 & $-0.01 \%$ & -0.00029 & $-0.18 \%$ \\
\hline Professional, technicians and scientists & 0.00011 & $0.34 \%$ & -0.00005 & $-0.03 \%$ \\
\hline Technicians and associate professionals & -0.00026 & $-0.78 \%$ & -0.00199 & $-1.25 \%$ \\
\hline Clerical support workers & -0.00131 & $-3.98 \%$ & -0.00061 & $-0.38 \%$ \\
\hline Transport, trade, service and sales workers & 0.00288 & $8.76 \%$ & 0.00328 & $2.07 \%$ \\
\hline Skilled agricultural, forestry and fishery workers & -0.00018 & $-0.55 \%$ & 0.00148 & $0.94 \%$ \\
\hline $\begin{array}{l}\text { Occupations unique to primary industry, } \\
\text { processing. manufacturing and utilities }\end{array}$ & 0.00051 & $1.56 \%$ & 0.01210 & $7.62 \%$ \\
\hline Plant and machine operators, and assemblers & -0.00017 & $-0.53 \%$ & 0.00442 & $2.79 \%$ \\
\hline Unskilled workers & 0.00022 & $0.67 \%$ & 0.01828 & $11.52 \%$ \\
\hline
\end{tabular}

Source: Own elaboration.

Table 3 shows the results of the detailed decomposition for occupational variables with normalized regression and log-linear models. We can appreciate clear differences when different occupations are taken into account. The negative sign of the unjustified component associated with high level occupations shows that women in high positions have shorter absences than men when workers are similar and the accidents have the same characteristics. Therefore, women who are in the high-level jobs have less absenteeism, while in the lowlevel positions the situation is reversed.

However, this differential effect disappears when aggregated decomposition is performed for the total sample. Because of that, an aggregate decomposition for different occupational groups estimated with duration models is carried out 
in the last part of the empirical work. The first occupational group includes high-level occupations (disaggregated between managers and professional technicians and scientists). The second one contains those intermediate-level jobs, and the third one includes unskilled workers.

The results for the aggregated decompositions break down by occupation are reported in Table 4. It is found that the justified component increases when the level of the occupation growths. In occupations associated with a higher qualification, more than $80 \%$ of the gender differences in the duration of sick leaves are justified by differences in characteristics included in the model. However, in unskilled occupations, two-thirds of the duration differences are due to a different behaviour of workers with similar characteristics. In other words, the gap observed for women in low-level occupations (with sick leaves 2.5 days longer than men) are mostly unjustified. However, when we go up in the job ladder, these differences disappear.

\section{Table 4}

Results from the aggregated decomposition by occupation of the estimated duration difference on the absence from work between men and women

\begin{tabular}{|c|c|c|c|c|}
\hline & & \\
\hline & & Difference & Justified & Unjustified \\
\hline \multicolumn{2}{|c|}{ High occupational level } & 4.0 & $85 \%$ & $15 \%$ \\
\hline \multicolumn{2}{|c|}{ Medium occupational level } & 3.2 & $42 \%$ & $58 \%$ \\
\hline \multicolumn{2}{|c|}{ Low occupational level } & 4.3 & $37 \%$ & $63 \%$ \\
\hline \multirow{2}{*}{ High level } & Managers & -1.3 & $46 \%$ & $54 \%$ \\
\hline & $\begin{array}{l}\text { Professional, technicians and } \\
\text { scientists }\end{array}$ & 4.6 & $77 \%$ & $23 \%$ \\
\hline
\end{tabular}

Source: Own elaboration.

The above result is even more pronounced when we disaggregate the group of high-skilled workers. In case of managers, the absence from work is longer for men and is explained mainly due to differences in behaviour. Therefore, in high-qualification jobs, the situation is reversed and men have more absenteeism than women.

The previous discussion has shown the existence of gender differences in the duration of absence from work that depends on the occupation and could be related to the workers' behaviour. These results seem to conclude that women who break the glass ceiling have a higher commitment to work. In opposition, men are less job commitment when they go up in the career ladder. 


\section{CONCLUDING REMARKS}

This work aims to widen the knowledge on gender differences between male and female Spanish workers in the recovery period after a workplace accident. The determinants of the recovery period after an accident at work have been studied in great detail in the North American economic literature. However, the studies for the European case about this topic are relatively scarce. At the same time, comparisons by gender have not been very common in this kind of bibliography, which is rather strange due to the huge number of works analyzing gender differences in other topics within the labour market. The current article seeks to cover, at least partly, this lack of research.

It is well known that, in general terms, women earn less than men and are promoted less frequently. At the same time, the economic literature on absenteeism has established that women are more likely to experience absence episodes than men. As a whole, this evidence has given rise to several explanations. Perhaps the most common ones are the glass ceiling and the sticky floors hypotheses to which the dead-end explanation has joined more recently.

In this paper, we find that the average duration of the recovery period after an accident is 16.8 days for men and 19.7 days for women. In other words, female recovery periods are $17.3 \%$ longer than those of men, which is a striking result because women tend to occupy less dangerous jobs than men. This empirical regularity might lead us to think that the question of ex-post duration moral hazard occurs more intensely among women than among men. Nonetheless, before concluding such a thing hastily a more rigorous statistical analysis has been carried out.

In order to do that, we have used decomposition techniques. We obtain that $61 \%$ of the whole difference cannot be justified by factors such as personal characteristics of the worker, different attributes of the job or the severity of the injury. If this unjustified gap is interpreted as collecting the different behaviour between men and women, it is followed that women are more prone to ex-post moral hazard conducts. This outcome is in line with previous studies about labour absenteeism.

But when we break down the database by level of occupation new insights are obtained. Those women working in the lowest jobs within the occupational ladder are the ones who perform the opportunistic behaviour studied here in a more intense manner. Nevertheless, we have to highlight that the higher the level of the job, the lower the difference attributable to ex-post moral hazard behaviour is found. What is more interesting, in the highest activities (managing occupations) women show less shirking behaviour than their male counterparts. Our interpretation of these facts is that those women who have broken the glass ceiling could be considered as more job-committed than men. 


\section{REFERENCES}

ALLEN, S. G. (1981a): "An empirical model of work attendance", en Review of Economics and Statistics, 63, pp. 77-87.

ALLEN, S. G. (1981b): "Compensation, safety and absenteeism: evidence from the paper industry", en Industrial and Labor Relations Review, 34, pp. 207218.

AMUEDO-DORANTES, C. (2002): "Work safety in the context of temporary employment: the Spanish experience" en Industrial and Labour Relations Review, 55(2), pp. 262-285.

BARMBY, T. and TREBLE J. (1991): "Absenteeism in a medium-sized manufacturing plant" en Applied Economics, 23, pp. 161-166.

BARMBY, T.; ORME, C. and TREBLE, J.G. (1991): "Worker absenteeism: an analysis using micro data”, en Economic Journal, 101, pp. 214-229.

BARMBY, T.; ERCOLANI, M. and TREBLE, J. (2002): "Sickness absence: an international comparison”, en Economic Journal, 112, pp. 315-331.

BLAU, F.D. and DeVARO, J. (2007): "New evidence on gender differences in promotion rates: an empirical analysis of a sample of new hires", en Industrial Relations, 46(3), pp. 511-550.

BLINDER, A.S. (1973): "Wage discrimination: reduced form and structural estimates", en Journal of Human Resource, 8, pp.436-455.

BOLDUC, D.; FORTIN, B.; LABRECQUE, F. and LANOIE, P. (2002): “Workers' compensation, moral hazard and the composition of workplace injuries", en Journal of Human Resource, 37(3), pp. 623-652.

BOOTH, A.L.; FRANCESCONI, M. and FRANK, J. (2003): "A sticky floors model of promotion, pay and gender", en European Economic Review, 47(2), pp. 295-322.

BRIDGES, S. and MUMFORD, K. (2001): "Absenteeism in the UK: a comparison across genders", en Manchester School, 69(3), pp. 276-284.

BROWN, S. (1994): "Dynamic implications of absence behaviour", en Applied Economics, 26, pp. 1163-1175.

BROWN, S. and SESSIONS, J.G. (1996): "The economics of absence: theory and evidence", en Journal of Economic Surveys, 10(1), pp. 23-53.

BUTLER, R.J.; BALDWIN, M.L. and JOHNSON, W.G. (2001): "The effects of worker heterogeneity on duration dependence: low-back claims in workers compensation", en Review of Economics and Statistics, 83(4), pp. 708-716.

CAMPOLIETI, M. (2001): "Recurrence in workers' compensation claims: estimates from a multiple sell hazard model", en Journal of Risk and Uncertainty, 23(1), pp. 75-94. 
CAMPOLIETI, M. and HYATT, D.E. (2006): "Further evidence on the 'Monday effect' in workers' compensation", en Industrial and Labor Relations Review, 59(3), pp. 438-50.

CAMPOLIETI, M.; GOLDENBERG, J. and HYATT, D.E. (2008): "Workplace violence and the duration of workers' compensation claims", en Relations Industrielles, 63(1), pp. 57-81.

COMISIONES OBRERAS (2004) Aproximación a los costes de la siniestralidad laboral en España, Informe de la Secretaria Confederal de Medio Ambiente y Salud Laboral.

CHAUDHURY, M. and $\mathrm{Ng}$, I. (1992): "Absenteeism predictors: least squares, rank regression, and model selection results", en Canadian Journal of Economics, 25, pp. 615-634.

CHEADLE, A.; FRANKLIN, G. and WOLFHAGEN, C. (1994): "Factors influencing the duration of work-related disability: a population-based study of Washington state workers' compensation", en American Journal of Public Health, 84(2), pp. 190-196.

CORRALES, H.; MARTíN-ROMÁN, A. and MORAL DE BLAS, A. (2008): "La duración de las bajas por accidente laboral en España: ¿Se justifican las diferencias entre comunidades autónomas?", en Revista de Economía Laboral, 5(1), pp. 73-98.

COX, D. R. (1972): "Regression models and life tables", en Journal of the Royal Statistical Society, 34 pp. 187-202.

CROSON, R. and GNEEZY, U. (2009): "Gender differences in preferences", en Journal of Economic Literature, 47(8), pp. 1-27.

DRAGO, R. and WOODEN, M. (1992): "The determinants of labor absence: economic factors and workgroup norms across countries", en Industrial and Labour Relations Review, 45, pp. 764-778.

ENGELLAND, A. and RIPHAHN, R.T. (2005): "Temporary contracts and employee effort", en Labour Economics, 12, pp. 281-299.

EVEN, W.E. and MACPHERSON, D.A. (1990): "Plant size and the decline of unionism", en Economics Letters, 32 pp. 393-398.

FAIRLIE, R.W. (1999): "The absence of the African-American owned business: an analysis of the dynamics of self-employment", en Journal of Labour Economics, 17, pp. 80-108.

FAIRLIE, R.W. (2005): "An extension of the Oaxaca-Blinder decomposition technique to logit and probit models, en Journal of Economic and Social Measurement, 30(4), pp. 305-316.

FORTIN, B. and LANOIE, P. (2001): "Incentive effects of workers' compensation: a survey". En Dionne, G. (ed.): Handbook of Insurance, Springer.

GAMERO-BURÓN, C. (2010): "Evaluación del coste por pérdida de jornadas laborales asociado al estrés laboral: propuesta para España", en Estudios de Economía Aplicada, 28 (3), pp. 1-20. 
GARCÍA MAINAR, I. and MONTUENGA GÓMEZ, V. (2009): "Causas de los accidentes de trabajo en España: análisis longitudinal con datos de panel", en Gaceta Sanitaria, 23(3), pp. 174-178.

GARCÍA-SERRANO, C; HERNANZ, V. and TOHARIA, L. (2010): "Mind the gap, please! The effect of temporary help agencies on the consequences of work accidents", en Journal of Labor Research, 31, pp. 162-182.

GROOT, W. and Van den BRINK, H.M. (1996): "Glass ceilings or dead ends: job promotion of men and women compared", en Economics Letters, 53(2), pp. 221-226.

GUADALUPE, M. (2003): "The hidden costs of fixed term contracts: the impact on work accidents", en Labour Economics, 10, pp. 339-357.

HENREKSON, M. and PERSSON, M. (2004): "The effects on sick leave of changes in the sickness insurance system", en Journal of Labor Economics, 22, pp. 87-113.

HERNANZ, V. and TOHARIA, L. (2006): "Do temporary contracts increase work accidents? A microeconometric comparison between Italy and Spain", en Labour, 20(3), pp. 475-504.

ICHINO, A. and MORETTI, E. (2009): "Biological gender differences, absenteeism, and the earnings gap", en American Economic Journal: Applied Economics, 1(1), pp. 183-218.

ICHINO, A. and RIPHAHN, R.T. (2005): "The effect of employment protection on worker effort: absenteeism during and after probation", en Journal of the European Economic Association, 3(1), pp. 120-143.

JOHANSSON, P. and PALME, M. (1996): "Do economic incentives affect work absence? Empirical evidence using Swedish micro data", en Journal of Public Economics, 59, pp.195-218.

JOHANSSON, P. and PALME, M. (2005): "Moral hazard and sickness insurance", en Journal of Public Economics, 89, pp.1879-1890.

JOHNSON, W.G. and ONDRICH, J. (1990): "The duration of post-injury absences from work", en Review of Economics and Statistics, 72(4), pp. 578-586.

KENYON, P. and DAWKINS, P. (1989): "A time series analysis of labour absence in Australia", en Review of Economics and Statistics, 71, pp. 232239.

KRUEGER, A.B. (1990): "Workers' compensation insurance and the duration of workplace injuries”, Working Paper 3253, NBER.

KRUEGER, A.B. and MEYER, B.D. (2002): "Labor supply effects of social insurance". En Auerbach, A.J. y Felstein, M. (ed.): Handbook of Public Economics, (pp. 2327-2392), North-Holland, Elsevier Science.

LAZEAR, E.P. and ROSEN, S. (1990): "Male-female wage differentials in job ladders", en Journal of Labour Economics, 8(1), pp. 106-123. 
LEIGH, J.P. (1983): "Sex differences in absenteeism", en Industrial Relations, 22(3), pp. 349-361.

LEIGH, J.P. (1984): "Unionization and absenteeism", en Applied Economics, 16, pp. 147-157.

LEIGH, J.P. (1985): "The effects of unemployment and the business cycle on absenteeism", en Journal of Economics and Business, 37, pp. 159-70.

MARTIN-ROMAN, A. and MORAL, A. (2008): "Moral hazard and gender differences in the workplace accidents insurance", en Empirical Economics Letters, 7(7), pp. 707-713.

MILLER, P.W. (2009): "The gender pay gap in the US: does sector make a difference?", en Journal of Labor Research, 30, pp. 52-74

MORAL DE BLAS, A., MARTÍN-ROMÁN A. and RODRÍGUEZ CABALLERO, J. C. (2010): "La antigüedad y las diferencias de esfuerzo entre trabajadores de distintas zonas geográficas: un estudio de los accidentes de trabajo", Estudios de Economía Aplicada, 28(1), PP. 1-20.

MORRISON, A.M., WHITE, R.P. and VAN VELSOR, E. and the Center for Creative Leadership (1987): Breaking the glass ceiling: can women reach the top of America's largest corporations? Reading, Addison-Wesley.

MOTELLÓN, E. and LÓPEZ-BAZO, E. (2005): "Discriminación por género en el acceso a la contratación indefinida", unpublished manuscript, VIII Encuentro de Economía Aplicada, Murcia.

NEUHAUSER, F. and RAPHAEL, S. (2004): "The effect of an increase in worker's compensation benefits on the duration and frequency of benefit receipt", en The Review of Economics and Statistics, 86(1), pp. 288-302.

NIELSEN, H.S. (1998): "Discrimination and detailed decomposition in a logit model", en Economics Letters, 61, pp. 115-120.

OAXACA, R.L. (1973): "Male-female wage differentials in urban labor markets", en International Economic Review, 14(3), pp. 693-709.

OAXACA, R.L. and RANSOM, M. (1999): "Identification in detailed wage decompositions", en Review of Economics and Statistics, 81(1), pp. 154-157.

PARINGER, L. (1983): “Women and absenteeism: health or economics?", en American Economic Review, 73(2), pp. 123-127.

POULIAKAS, K. and THEODOROPOULOS, N. (2010): "An Inquiry into the Theory, Causes and Consequences of Monitoring Indicators of Health and Safety at Work". IZA Discussion Paper No. 4734.

RANSOM, M. and OAXACA, R.L. (2005): "Intrafirm mobility and sex differences in pay", en Industrial and Labour Relations Review, 58(2), pp. 219-237.

RODRÍGUEZ-GUTIÉRREZ, C. and CANAL-DOMÍNGUEZ, J. F. (2012): "Is workers' effort sensitive to contract type and firm ownership? The Spanish case", en Revista de Economía Laboral, 9, pp. 1-27. 
VANDENHEUVEL, A. and WOODEN, M. (1995): "Do explanations of absenteeism differ for men and women?", en Human Relations, 48(11), pp. 13091329.

VISTNES, J.P. (1997): "Gender differences in days lost from work due to illness", en Industrial Labour Relations Review, 50(2), pp. 304-323.

WALKER, J.R. (2009): "Earnings, effort, and work flexibility of self-employed women and men: the case of St. Croix County, Wisconsin", en Journal of Labor Research, 30, pp. 269-288

YUN, M.S. (2004): "Decomposing differences in the first moment", en Economics Letters, 82, pp. 275-280.

YUN, M. S. (2005): "Normalized equation and decomposition analysis: computation and inference", IZA Discussion Paper 1822, Tulane University. 


\section{Appendix I}

Table A1

Summary of variables

\begin{tabular}{|c|c|c|c|c|c|}
\hline & & \multicolumn{2}{|c|}{$\begin{array}{c}\text { Hard-to-diagnose } \\
\text { work-related injuries }\end{array}$} & \multicolumn{2}{|c|}{ Days off work } \\
\hline & & $\%$ Women & Total & Men & Women \\
\hline \multirow{4}{*}{$\begin{array}{l}\text { Age at the time of } \\
\text { accident }\end{array}$} & $16-30$ years & $24 \%$ & 585205 & 14.0 & 16.7 \\
\hline & $30-45$ years & $21 \%$ & 527636 & 17.7 & 21.1 \\
\hline & $45-60$ years & $21 \%$ & 251488 & 21.0 & 24.3 \\
\hline & More than 60 years & $22 \%$ & 20972 & 23.1 & 28.1 \\
\hline \multirow{10}{*}{ Occupation } & Armed Forces & $16 \%$ & 180 & 25.3 & 22.4 \\
\hline & Managers & $24 \%$ & 3388 & 22.5 & 21.1 \\
\hline & Professionals, technicians and scientists & $56 \%$ & 20978 & 21.1 & 25.3 \\
\hline & Technicians and associate professionals & $35 \%$ & 39040 & 20.8 & 21.5 \\
\hline & Clerical support workers & $57 \%$ & 53672 & 18.6 & 19.5 \\
\hline & Transport, trade, service and sales workers & $47 \%$ & 191719 & 17.9 & 20.5 \\
\hline & Skilled agricultural, forestry and fishery workers & $16 \%$ & 24081 & 19.8 & 19.5 \\
\hline & $\begin{array}{l}\text { Occupations unique to primary industry, } \\
\text { processing, manufacturing and utilities }\end{array}$ & $8 \%$ & 468017 & 16.7 & 18.3 \\
\hline & Plant and machine operators, and assemblers & $9 \%$ & 188768 & 17.4 & 18.4 \\
\hline & Unskilled workers & $26 \%$ & 395458 & 15.4 & 19.1 \\
\hline \multirow{4}{*}{$\begin{array}{l}\text { Social Security } \\
\text { Scheme }\end{array}$} & General & $22 \%$ & 1328864 & 16.7 & 19.8 \\
\hline & Special Scheme for Agriculture & $29 \%$ & 42155 & 17.2 & 17.3 \\
\hline & Special Scheme for Sea workers & $5 \%$ & 8180 & 25.4 & 25.2 \\
\hline & Special Scheme for Coal mining & $2 \%$ & 6102 & 23.7 & 22.5 \\
\hline \multirow{6}{*}{ Type of contract } & Permanent contract & $22 \%$ & 594900 & 18.4 & 21.0 \\
\hline & Contract for a specific project or service & $11 \%$ & 357426 & 15.9 & 18.2 \\
\hline & Casual contract to cover demand for production & $26 \%$ & 228902 & 14.7 & 17.8 \\
\hline & Apprenticeship contract & $26 \%$ & 32482 & 12.8 & 16.0 \\
\hline & Other fixed-term contracts & $42 \%$ & 128043 & 16.4 & 19.4 \\
\hline & Unclassified & $28 \%$ & 43548 & 19.0 & 24.1 \\
\hline \multirow{9}{*}{ Size of firm } & Unclassified & $25 \%$ & 272528 & 16.6 & 19.4 \\
\hline & $1-9$ workers & $16 \%$ & 209663 & 17.6 & 20.9 \\
\hline & $10-25$ workers & $14 \%$ & 212154 & 16.2 & 19.1 \\
\hline & $26-49$ workers & $16 \%$ & 157861 & 15.8 & 18.4 \\
\hline & $50-100$ workers & $21 \%$ & 147458 & 15.9 & 18.2 \\
\hline & $101-249$ workers & $26 \%$ & 151005 & 16.3 & 18.8 \\
\hline & 250-499 workers & $31 \%$ & 88103 & 17.3 & 19.0 \\
\hline & 500-1000 workers & $35 \%$ & 56841 & 18.3 & 20.4 \\
\hline & More than 1000 workers & $36 \%$ & 89688 & 20.8 & 23.8 \\
\hline
\end{tabular}


Table A1 (continue)

Summary of variables

\begin{tabular}{|c|c|c|c|c|c|}
\hline & & \multicolumn{2}{|c|}{$\begin{array}{c}\text { Hard-to-diagnose } \\
\text { work-related injuries }\end{array}$} & \multicolumn{2}{|c|}{ Days off work } \\
\hline & & $\%$ Women & Total & Men & Women \\
\hline Economic activity & $\begin{array}{l}\text { Agriculture, hunting, forestry and fishing } \\
\text { Electricity, gas and water supply } \\
\text { Manufacture I } \\
\text { Manufacture II } \\
\text { Manufacture III } \\
\text { Construction } \\
\text { Wholesale, retail trade, hotels and restaurants } \\
\text { Transport, storage and communications } \\
\text { Financial and insurance activities, Renting and } \\
\text { business activities } \\
\text { Other services }\end{array}$ & $\begin{array}{c}23 \% \\
4 \% \\
14 \% \\
8 \% \\
23 \% \\
3 \% \\
36 \% \\
10 \% \\
46 \% \\
43 \% \\
\end{array}$ & $\begin{array}{c}59914 \\
13012 \\
70035 \\
162079 \\
142852 \\
312422 \\
266524 \\
78858 \\
123462 \\
156143\end{array}$ & $\begin{array}{l}18.6 \\
21.6 \\
15.9 \\
16.8 \\
16.0 \\
16.1 \\
16.0 \\
18.9 \\
16.1 \\
19.6\end{array}$ & $\begin{array}{l}17.7 \\
21.0 \\
17.1 \\
18.4 \\
18.7 \\
18.7 \\
18.4 \\
20.8 \\
18.9 \\
23.9\end{array}$ \\
\hline Level of severity & $\begin{array}{l}\text { Serious or very serious accidents } \\
\text { Minor accidents }\end{array}$ & $\begin{array}{l}26 \% \\
22 \%\end{array}$ & $\begin{array}{c}2936 \\
1382365 \\
\end{array}$ & $\begin{array}{l}46.1 \\
16.8\end{array}$ & $\begin{array}{l}43.6 \\
19.7\end{array}$ \\
\hline $\begin{array}{l}\text { Number of hours } \\
\text { worked previous to } \\
\text { accident }\end{array}$ & $\begin{array}{l}\text { Two hours or less } \\
\text { Between two and six hours } \\
\text { More than six hours }\end{array}$ & $\begin{array}{l}24 \% \\
21 \% \\
20 \%\end{array}$ & $\begin{array}{l}518118 \\
541147 \\
326036\end{array}$ & $\begin{array}{l}16.5 \\
16.8 \\
17.3\end{array}$ & $\begin{array}{l}19.6 \\
19.5 \\
20.5\end{array}$ \\
\hline Shiftwork & $\begin{array}{l}\text { Morning shift } \\
\text { Evening shift } \\
\text { Night shift }\end{array}$ & $\begin{array}{l}22 \% \\
23 \% \\
22 \%\end{array}$ & $\begin{array}{l}895597 \\
369146 \\
120558\end{array}$ & $\begin{array}{l}16.5 \\
17.2 \\
17.7\end{array}$ & $\begin{array}{l}19.4 \\
20.1 \\
21.0\end{array}$ \\
\hline $\begin{array}{l}\text { Day week of the } \\
\text { accident }\end{array}$ & $\begin{array}{l}\text { Monday } \\
\text { From Tuesday to Friday } \\
\text { Weekend }\end{array}$ & $\begin{array}{l}20 \% \\
22 \% \\
32 \%\end{array}$ & $\begin{array}{l}330716 \\
946384 \\
108201\end{array}$ & $\begin{array}{l}16.0 \\
16.9 \\
18.6\end{array}$ & $\begin{array}{l}19.2 \\
19.8 \\
20.2\end{array}$ \\
\hline $\begin{array}{l}\text { Place of the } \\
\text { accident }\end{array}$ & $\begin{array}{l}\text { At the usual job or another place } \\
\text { On journey }\end{array}$ & $\begin{array}{l}20 \% \\
38 \%\end{array}$ & $\begin{array}{c}1246221 \\
139080\end{array}$ & $\begin{array}{l}16.4 \\
22.0\end{array}$ & $\begin{array}{l}18.5 \\
25.7\end{array}$ \\
\hline $\begin{array}{l}\text { Year of the } \\
\text { accident }\end{array}$ & $\begin{array}{l}1997 \\
1998 \\
1999 \\
2000 \\
2001\end{array}$ & $\begin{array}{l}21 \% \\
21 \% \\
22 \% \\
23 \% \\
23 \%\end{array}$ & $\begin{array}{l}219225 \\
251031 \\
277321 \\
328212 \\
309512\end{array}$ & $\begin{array}{l}17.3 \\
17.0 \\
16.7 \\
16.7 \\
16.5\end{array}$ & $\begin{array}{l}19.9 \\
19.9 \\
19.7 \\
19.8 \\
19.5\end{array}$ \\
\hline $\begin{array}{l}\text { Hospitalization } \\
\text { required }\end{array}$ & $\begin{array}{l}\text { No } \\
\text { Yes }\end{array}$ & $\begin{array}{l}26 \% \\
22 \%\end{array}$ & $\begin{array}{c}116244 \\
1269057\end{array}$ & $\begin{array}{l}16.5 \\
20.3\end{array}$ & $\begin{array}{l}19.2 \\
25.0\end{array}$ \\
\hline Usual work & $\begin{array}{l}\text { No } \\
\text { Yes }\end{array}$ & $\begin{array}{l}40 \% \\
22 \%\end{array}$ & $\begin{array}{c}1347632 \\
37669\end{array}$ & $\begin{array}{l}22.2 \\
16.7\end{array}$ & $\begin{array}{l}25.7 \\
19.4\end{array}$ \\
\hline TOTAL & & $22 \%$ & 1385301 & 16.8 & 19.7 \\
\hline
\end{tabular}

Source: Own elaboration. 


\section{Table A2}

Results from the log-logistic model on duration of the absence from work caused by a work-related accident

\begin{tabular}{|c|c|c|c|c|}
\hline & \multicolumn{4}{|c|}{ Log-logistic Model } \\
\hline & \multicolumn{2}{|c|}{ Women } & \multicolumn{2}{|c|}{ Men } \\
\hline \multicolumn{5}{|l|}{ SCALE PARAMETER } \\
\hline \multicolumn{5}{|l|}{ Age at the time of the accident (ref: 16-30) } \\
\hline $30-45$ years & 0.1504 & * & 0.1528 & * \\
\hline $45-60$ years & 0.2797 & * & 0.2933 & * \\
\hline More than 60 years & 0.3955 & * & 0.3946 & * \\
\hline \multicolumn{5}{|l|}{ Occupation (ref: elementary occupations) } \\
\hline Armed forces & 0.1240 & & -0.0126 & \\
\hline Managers & -0.0546 & & 0.1184 & * \\
\hline Professional, technicians and scientists & -0.0024 & & 0.0657 & * \\
\hline Technicians and associate professionals & -0.0376 & * & 0.0969 & * \\
\hline Clerical support workers & -0.0430 & * & 0.0392 & * \\
\hline Transport, trade, service and sales workers & 0.0216 & * & 0.0515 & * \\
\hline Skilled agricultural, forestry and fishery workers & 0.0377 & * & 0.0386 & * \\
\hline $\begin{array}{l}\text { Occupations unique to primary industry, } \\
\text { processing. manufacturing and utilities }\end{array}$ & -0.0118 & * & 0.0182 & * \\
\hline Plant and machine operators, and assemblers & -0.0009 & & 0.0288 & * \\
\hline \multicolumn{5}{|l|}{ Social Security Scheme (ref: General) } \\
\hline Special Scheme for Agriculture & 0.0216 & & 0.0454 & * \\
\hline Special Scheme for Sea workers & 0.0824 & & 0.2187 & * \\
\hline Special Scheme for Coal mining & 0.2046 & * & 0.1456 & * \\
\hline \multicolumn{5}{|l|}{ Type of contract (ref: permanent contract) } \\
\hline Contract for a specific project or service & -0.0169 & * & -0.0246 & * \\
\hline Casual contract to cover demand for production & -0.0156 & * & -0.0432 & * \\
\hline Apprenticeship contract & -0.0933 & * & -0.1190 & * \\
\hline Other fixed-term contracts & 0.0037 & & -0.0138 & * \\
\hline Unclassified & 0.0405 & * & 0.0052 & \\
\hline \multicolumn{5}{|l|}{ Tenure in the firm (tenure-50) } \\
\hline Tenure & 0.0005 & * & 0.0003 & * \\
\hline Squared tenure & $-1.2 \mathrm{E}-06$ & & $-3.2 \mathrm{E}-07$ & * \\
\hline \multicolumn{5}{|l|}{ Size of firm (ref: size unknown) } \\
\hline 1-9 workers & 0.0748 & * & 0.0659 & * \\
\hline $10-25$ workers & 0.0061 & & -0.0080 & * \\
\hline $26-49$ workers & -0.0311 & * & -0.0310 & * \\
\hline 50-100 workers & -0.0367 & * & -0.0358 & * \\
\hline $101-249$ workers & -0.0221 & * & -0.0271 & * \\
\hline 250-499 workers & -0.0199 & * & 0.0002 & \\
\hline $500-1000$ workers & 0.0109 & & 0.0208 & * \\
\hline More than 1000 workers & 0.0797 & * & 0.0858 & * \\
\hline
\end{tabular}


Table A2 (continue)

Results from the log-logistic model on duration of the absence from work caused by a work-related accident

\begin{tabular}{|c|c|c|c|c|}
\hline & \multicolumn{4}{|c|}{ Log-logistic Model } \\
\hline & \multicolumn{2}{|c|}{ Women } & \multicolumn{2}{|c|}{ Men } \\
\hline \multicolumn{5}{|l|}{ Economic activity (ref: other service activities ) } \\
\hline Agriculture, hunting, forestry and fishing & -0.0816 & * & 0.0312 & * \\
\hline Electricity, gas and water supply & -0.1512 & * & -0.0174 & \\
\hline Manufacture I & -0.1330 & * & -0.0634 & * \\
\hline Manufacture II & -0.1105 & * & -0.0721 & * \\
\hline Manufacture III & -0.0836 & * & -0.0551 & * \\
\hline Construction & -0.1013 & * & -0.0322 & * \\
\hline Wholesale, retail trade, hotels and restaurant & -0.0931 & * & -0.0750 & * \\
\hline Transport, storage and communications & -0.0568 & * & -0.0139 & * \\
\hline Renting and business activities. & -0.0952 & * & -0.0657 & * \\
\hline \multicolumn{5}{|l|}{ Mode of injury (ref: people falls) } \\
\hline Falling objects & -0.0844 & * & -0.0931 & * \\
\hline Stepping on objects & -0.0831 & * & -0.0876 & * \\
\hline Striking against objects & -0.0658 & * & -0.1126 & * \\
\hline Caught in or between objects & -0.0959 & * & -0.0412 & * \\
\hline Overexertion & -0.1136 & * & -0.1817 & * \\
\hline Exposure to or contact & 0.0399 & & -0.1903 & * \\
\hline Explosions and fires & -0.1704 & & -0.0163 & \\
\hline Running over & 0.2805 & * & 0.2337 & * \\
\hline \multicolumn{5}{|c|}{ Geographical area of the accident (ref: Ceuta and Melilla) } \\
\hline Andalucía & -0.0826 & & -0.0875 & * \\
\hline Aragón & 0.0578 & & 0.0704 & * \\
\hline Asturias & 0.1654 & * & 0.2206 & * \\
\hline Baleares & 0.0378 & & 0.0070 & \\
\hline Canarias & -0.0875 & * & -0.1503 & * \\
\hline Cantabria & 0.1025 & * & 0.1376 & * \\
\hline Castilla y León & 0.0191 & & -0.0037 & \\
\hline Castilla La Mancha & -0.0617 & & -0.0564 & * \\
\hline Cataluña & -0.0391 & & -0.0366 & * \\
\hline Com. Valenciana & 0.0342 & & -0.0071 & \\
\hline Extremadura & -0.0267 & & -0.0226 & \\
\hline Galicia & 0.2144 & * & 0.2017 & * \\
\hline Madrid & -0.0930 & * & -0.0921 & * \\
\hline Murcia & -0.0906 & & -0.0051 & \\
\hline Navarra & -0.0089 & & -0.0304 & \\
\hline País Vasco & 0.1247 & * & 0.1477 & * \\
\hline La Rioja & -0.1141 & * & -0.1182 & * \\
\hline \multicolumn{5}{|l|}{ Level of severity (ref: serious or very serious) } \\
\hline Minor & -0.5124 & * & -0.7903 & * \\
\hline
\end{tabular}


Table A2 (continue)

Results from the log-logistic model on duration of the absence from work caused by a work-related accident

\begin{tabular}{|c|c|c|c|c|}
\hline & \multicolumn{4}{|c|}{ Log-logistic Model } \\
\hline & \multicolumn{2}{|c|}{ Women } & \multicolumn{2}{|c|}{ Men } \\
\hline \multicolumn{5}{|c|}{ Part of the body injured (ref: multiple injuries) } \\
\hline Neck & 0.0166 & & -0.0896 & * \\
\hline Chest, back and sides & -0.1887 & * & -0.2481 & * \\
\hline Low back and abdominal area & -0.1801 & * & -0.1927 & * \\
\hline Hands & -0.0778 & * & -0.0593 & * \\
\hline Upper extremities (except hands) & -0.0103 & & -0.0215 & \\
\hline Feet & -0.2218 & * & -0.1094 & * \\
\hline Lower extremities (except feet) & -0.1004 & * & 0.0537 & * \\
\hline Internal organs & -0.0443 & & 0.3495 & * \\
\hline \multicolumn{5}{|c|}{ Number of hours worked when accident occurs (ref: two hours or less) } \\
\hline 2-6 hours & 0.0170 & * & 0.0184 & * \\
\hline More than six hours & 0.0182 & * & 0.0165 & * \\
\hline \multicolumn{5}{|l|}{ Shiftwork (ref: morning shift) } \\
\hline Evening shift & 0,0089 & * & 0,0034 & \\
\hline Night shift & $-0,0055$ & & $-0,0034$ & \\
\hline \multicolumn{5}{|c|}{ Place of the accident (ref: at the usual job or another workplace) } \\
\hline On journey & 0.1130 & * & 0.1029 & * \\
\hline \multicolumn{5}{|l|}{ Day of the week (ref: monday) } \\
\hline From Tuesday to Friday & 0.0363 & * & 0.0475 & * \\
\hline Weekend & 0.0553 & * & 0.0911 & * \\
\hline \multicolumn{5}{|l|}{ Year of the accident (ref: 2001) } \\
\hline 1997 & 2.3257 & * & 1.3022 & * \\
\hline 1998 & 2.0261 & * & 0.9460 & * \\
\hline 1999 & 1.3822 & * & 0.5429 & * \\
\hline 2000 & 0.9297 & * & 0.3436 & * \\
\hline \multicolumn{5}{|l|}{ Compensation } \\
\hline Compensation & $-7.76 \mathrm{E}-07$ & & 3.68E-06 & * \\
\hline \multicolumn{5}{|l|}{ Unemployment rate } \\
\hline Unemployment rate & -0.1775 & & -0.1484 & * \\
\hline \multicolumn{5}{|l|}{ SHAPE PARAMETER } \\
\hline On journey & 0.0208 & * & 0.0431 & * \\
\hline Minor severity & -0.0730 & * & -0.1607 & * \\
\hline Hospitalization & 0.0298 & * & 0.0388 & * \\
\hline Sample size & \multicolumn{2}{|c|}{306710} & \multicolumn{2}{|c|}{1078591} \\
\hline Log-likelihood & \multicolumn{2}{|c|}{-388894.27} & \multicolumn{2}{|c|}{-1381968.3} \\
\hline
\end{tabular}

${ }^{*}$ means significance at $5 \%$

Source: Own elaboration. 


\section{Appendix II}

Normalized regression

From the following expression:

$$
Y=\varphi\left[b_{\boldsymbol{0}}+\left(\sum_{i=2}^{I} u_{i} U_{i}+\sum_{j=2}^{J} v_{j} V_{j}\right)+\sum_{k=1}^{K} b_{k} X_{k}+\varepsilon\right]
$$

When $U$ and $V$ are sets of $i$ and $j$ dummy variables, $\mathrm{X}$ a group of $K$ continuous variables and $\varphi$ a non-linear function.

It can be obtained a normalized regression which does not omit the reference groups in the estimating equation. The expression looks like:

$$
Y=\varphi\left[b_{o}^{*}+\left(\sum_{i=1}^{I} u_{i}^{*} U_{i}+\sum_{j=1}^{J} v_{j}^{*} V_{j}\right)+\sum_{k=1}^{K} b_{k} X_{k}+\varepsilon\right]
$$

Where:

$$
\begin{aligned}
& b_{o}^{*}=b_{0}+\bar{u}+\bar{v} \\
& u_{i}^{*}=u_{i}-\bar{u} \\
& v_{i}^{*}=v_{i}-\bar{v}
\end{aligned}
$$

And

$$
\bar{u}=\frac{\sum_{i=1}^{I} u_{i}}{I}, \bar{v}=\frac{\sum_{j=1}^{J} v_{j}}{J}
$$

With

$$
u_{1}=v_{1}=0
$$


